\title{
Impact Assessment of Twenty-Two Days Fishing Ban in the Major Spawning Grounds of Tenualosa ilisha (Hamilton, 1822) on its Spawning Success in Bangladesh
}

Md Anisur Rahman¹, Md Mehedi Hasan Pramanik ${ }^{1 *}$, Flura', Tayfa Ahmed ${ }^{1}$, Md Monjurul Hasan ${ }^{1}$, Masud Hossain Khan ${ }^{1}$ and Yahia Mahmud ${ }^{2}$

${ }^{1}$ Bangladesh Fisheries Research Institute, Riverine Station, Chandpur, Bangladesh

${ }^{2}$ Bangladesh Fisheries Research Institute, Headquarter, Mymensingh, Bangladesh

\begin{abstract}
This study was conducted to evaluate the impact of twenty-two days fishing ban from October 22-November 02 , 2016 on the spawning success of Hilsa in the major spawning grounds of Hilsa. Fishing ban during the spawning season have substantial role in the successful reproduction of Hilsa found from the present study. Among all the Hilsa captured in and around the spawning grounds of Hilsa, male and female were estimated to make up $34 \%$ and $64 \%$ respectively of the total catch, suggesting a male to female sex ratio of about 1:1.94. In the year 2016 during the major spawning period in the major spawning grounds $43.93 \%$ spent Hilsa was found and calculated egg production was $628291 \mathrm{~kg}$ and the estimated Jatka production was 39,268 crore which were found to be much higher than the previous years. Increased production of Hilsa eggs and Jatka indicates a positive impact of twenty-two days fishing ban during the spawning season. Percentages of gravid and oozing Hilsa were also found higher compared to previous fishing ban periods. In the spawning grounds, relatively higher amount of spent Hilsa and Jatka were observed whereas fewer spent Hilsa and Jatka were found in the adjacent areas of spawning grounds. Besides Jatka, spawn and fries of other fish species were also found in higher quantity in and around the spawning areas of Hilsa than previous years which indicates fishing ban might have positive impacts on successful breeding and maintenance of biodiversity of other fish species. Overall, twenty-two days fishing ban was found to be very effective for successful spawning of Hilsa.
\end{abstract}

Keywords: Tenualosa ilisha; Fishing ban; Hilsa; Spawning ground; River Meghna; Bangladesh

\section{Introduction}

Hilsa (Tenualosa ilisha, Ham. 1822) locally known as Ilish has been designated as the national fish of Bangladesh. It's a popular food fish in South Asia as well. Hilsa contributes about $11 \%$ of the total fish production and about $1 \%$ to the Gross Domestic Product (GDP) of Bangladesh [1]. About 2 million people directly or indirectly involved with the catching and trading of Hilsa fish in the country [1]. Hilsa is anadromous and has a typical life cycle that follows general pattern of breeding in the upstream in freshwater and the larvae hatching from free floating eggs. The immature young stages grow out in river channels and then descend to the sea for feeding and growing before returning to the rivers as matured gravid Hilsa to complete the cycle. It's a highly fecund fish that may produce up to 2 million eggs. Although Hilsa spawn all the year round, they have a major spawning season during the Bengali month of Ashwin-Kartik (September-October) based on the full moon phase. Matured gravid Hilsa has been extensively caught during the major spawning season from the major spawning grounds. The juveniles of Hilsa known as Jatka have also been caught during their seaward migration in some of the major rivers of the country. These are the most important reasons along with some other reasons which are responsible for the decline of Hilsa fishery in the country. In the above circumstances, considering the importance of Hilsa in nutrition, employment and economy, the Hilsa Fishery Management Action Plan (HFMAP) was prepared for the development, management and conservation of Hilsa incorporating the objectives of protecting the nursery and spawning grounds and banning indiscriminate capture of Hilsa. Each year to conserve Jatka and brood Hilsa, the fishing ban is being implemented by the Department of Fisheries (DoF) with related stakeholders including the law enforcing agencies such as Navy, Coast guards, River Police etc. and that management action is administered by the Ministry of Fisheries and Livestock (MoFL) based on the experimental findings of Bangladesh Fisheries Research Institute (BFRI), Riverine Station (RS) (Table 1).

Five Hilsa sanctuaries and four major spawning grounds in the coastal and freshwater areas of the country have been established under the 'Protection and Conservation of fish Act-1950' for the effective conservation of Jatka and brood Hilsa in the major nursery and spawning areas (Figures 1 and 2, Tables 2 and 3).

It has been identified from the previous research activities conducted by BFRI; RS Hilsa Research Team that peak spawning period of matured gravid Hilsa has been vastly associated with the lunar periodicity or specifically with full moon phase. During this period, large number of matured gravid Hilsa has been captured indiscriminately from their major spawning ground and has negative impacts on the spawning and stocks as well. To ensure their safe and successful spawning, 4 days before the full moon day of the Bengali month Ashwins (1423 Bengali year) risen moon, full moon day and 17 days after the full moon day altogether 22 days has been fixed up as the major spawning period of Hilsa (Figure 3). This twenty-two days (October 12-November 02, 2016)

*Corresponding author: Md. Mehedi Hasan Pramanik, Bangladesh Fisheries Research Institute, Riverine Station, Chandpur, Bangladesh, Tel: +880-1720618000; E-mail: mehedibfri@gmail.com

Received May 03, 2017; Accepted July 04, 2017; Published July 06, 2017

Citation: Rahman MA, Pramanik MMH, Flura, Ahmed T, Hasan MM, et al. (2017) Impact Assessment of Twenty-Two Days Fishing Ban in the Major Spawning Grounds of Tenualosa ilisha (Hamilton, 1822) on its Spawning Success in Bangladesh. J Aquac Res Development 8: 489. doi: 10.4172/2155-9546.1000489

Copyright: @ 2017 Rahman MA, et al. This is an open-access article distributed under the terms of the Creative Commons Attribution License, which permits unrestricted use, distribution, and reproduction in any medium, provided the original author and source are credited. 
Citation: Rahman MA, Pramanik MMH, Flura, Ahmed T, Hasan MM, et al. (2017) Impact Assessment of Twenty-Two Days Fishing Ban in the Major Spawning Grounds of Tenualosa ilisha (Hamilton, 1822) on its Spawning Success in Bangladesh. J Aquac Res Development 8: 489. doi: 10.4172/2155-9546.1000489

Page 2 of 12

\begin{tabular}{|c|c|c|}
\hline Year & Management system & Management type \\
\hline $2001-02$ & Conventional & Without any management \\
\hline $2002-03$ & Conventional & Traditional (improved) management \\
\hline 2003-04 & Jatka conservation & Protection system \\
\hline 2004-05 & Jatka conservation & Protection system \\
\hline $2005-06$ & Jatka conservation+sanctuary & Full Moon basis \\
\hline $2006-07$ & Jatka conservation+sanctuary+10 days Hilsa fishing ban & Full Moon basis \\
\hline 2007-08 & Jatka conservation+sanctuary+10 days Hilsa fishing ban & Full Moon basis \\
\hline $2008-09$ & Jatka conservation+sanctuary+10 days Hilsa fishing ban & Full Moon basis \\
\hline $2009-10$ & Jatka conservation+sanctuary+10 days Hilsa fishing ban & Full Moon basis \\
\hline $2010-11$ & Jatka conservation+sanctuary+10 days Hilsa fishing ban & Full Moon basis \\
\hline $2011-12$ & Jatka conservation+sanctuary+10 days Hilsa fishing ban & Full Moon basis \\
\hline $2012-13$ & Jatka conservation+sanctuary+11 days Hilsa fishing ban & Full Moon basis \\
\hline 2013-14 & Jatka conservation+sanctuary+11 days Hilsa fishing ban & Full Moon basis \\
\hline $2014-15$ & Jatka conservation+sanctuary+11 days Hilsa fishing ban & Full Moon basis \\
\hline $2015-16$ & Jatka conservation+sanctuary+15 days Hilsa fishing ban & Full Moon basis \\
\hline $2016-17$ & Jatka conservation+sanctuary +22 days Hilsa fishing ban & $\begin{array}{l}\text { Full Moon basis } \\
\text { (with new Moon) }\end{array}$ \\
\hline
\end{tabular}

Table 1: Management system for Jatka and brood Hilsa conservation in Bangladesh.

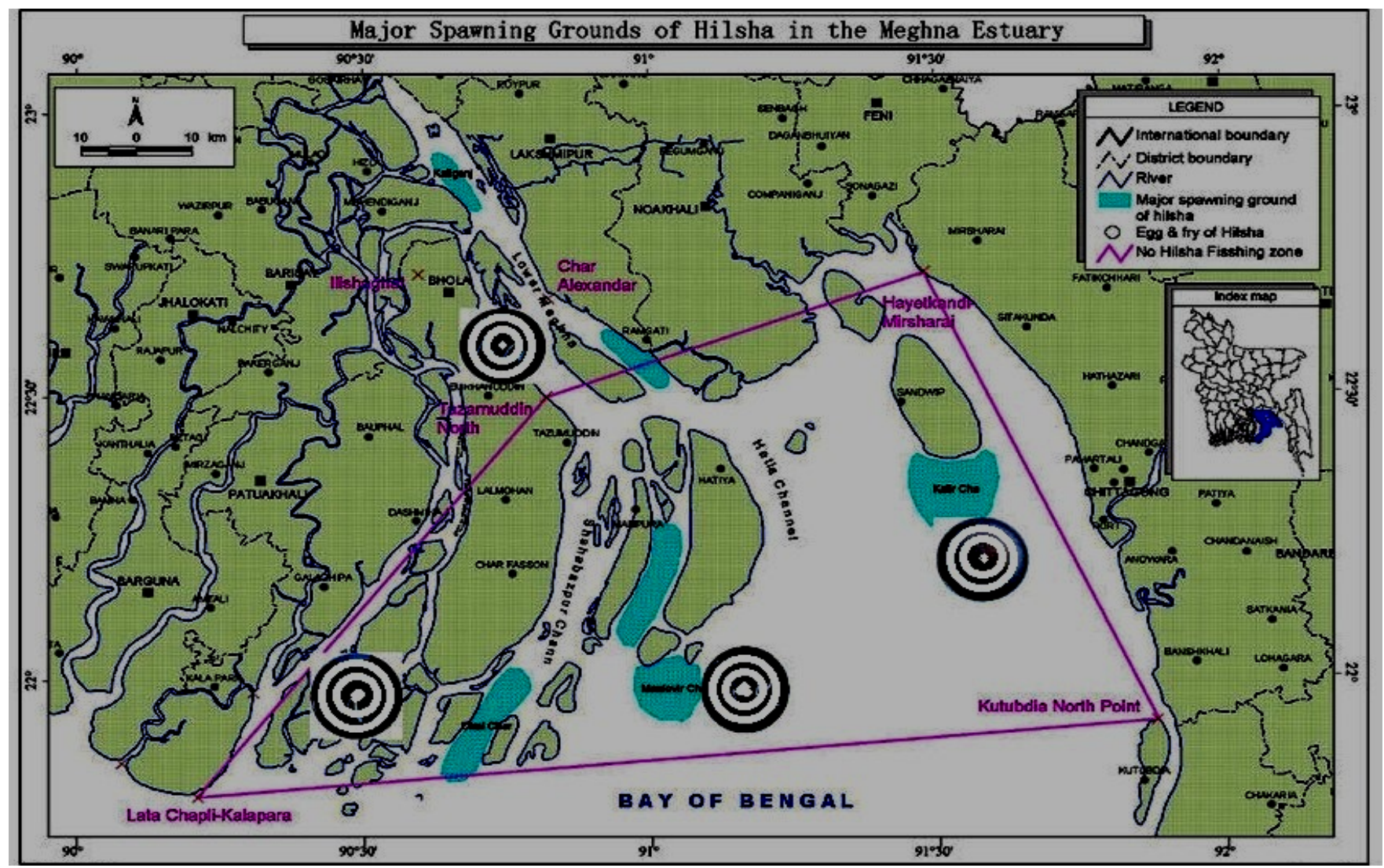

Figure 1: Major spawning grounds of Hilsa in the Meghna River estuary (Source: BFRI \& GEF).

has been banned for fishing in the sea, coastal areas along with the rivers by all sorts of commercial trawlers under the Marine Fisheries Ordinance 1983 , section 55, subsection 2 (D) for safe migration and smooth spawning of Hilsa. The previous ban period was 15 days (25 September-09 October 2015) and has been extended up to 22 days and the ban period time has also been changed for the better spawning of Hilsa.

\section{Methodology}

\section{Preparation of Hilsa research team}

The Hilsa Research Team of BFRI, RS, Chandpur carried out all the investigations. Two ways were selected for sampling and data collection such as: 
Citation: Rahman MA, Pramanik MMH, Flura, Ahmed T, Hasan MM, et al. (2017) Impact Assessment of Twenty-Two Days Fishing Ban in the Major Spawning Grounds of Tenualosa ilisha (Hamilton, 1822) on its Spawning Success in Bangladesh. J Aquac Res Development 8: 489. doi: 10.4172/2155-9546.1000489

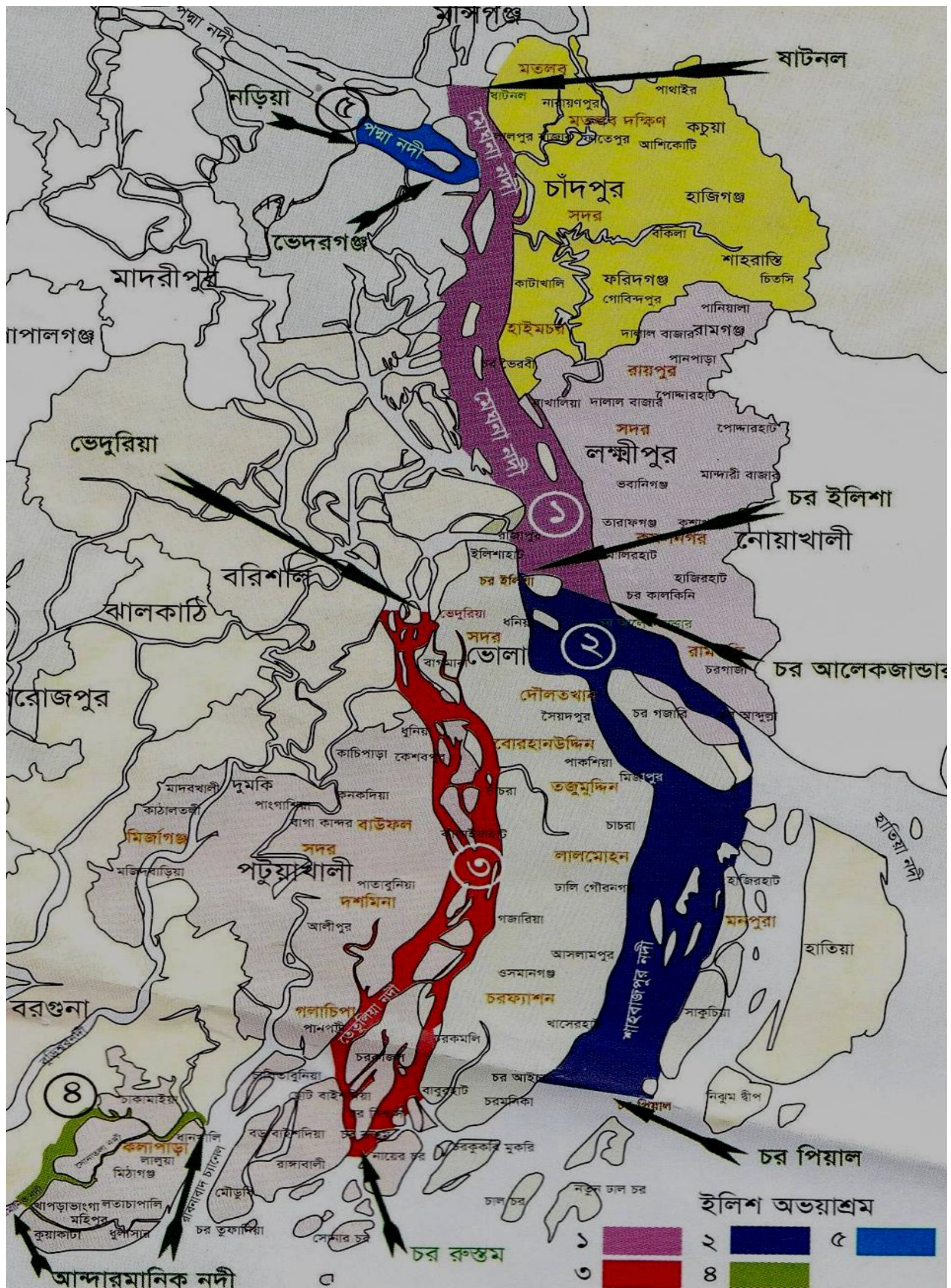

Figure 2: Hilsa sanctuaries in Bangladesh (Source: MoFL). 
Citation: Rahman MA, Pramanik MMH, Flura, Ahmed T, Hasan MM, et al. (2017) Impact Assessment of Twenty-Two Days Fishing Ban in the Major Spawning Grounds of Tenualosa ilisha (Hamilton, 1822) on its Spawning Success in Bangladesh. J Aquac Res Development 8: 489. doi: 10.4172/2155-9546.1000489

Page 4 of 12

\begin{tabular}{|c|c|c|c|c|}
\hline SI. No. & Sanctuary area & Area length & River & Ban period \\
\hline 1 & From Shatnol to Char Alexander & $100 \mathrm{~km}$ & Lower Meghna estuary & March-April \\
\hline 2 & Char Ilisha to Char Pial & $90 \mathrm{~km}$ & $\begin{array}{c}\text { Stretch of Shahbajpur Channel, a } \\
\text { tributary of the Meghna river }\end{array}$ & March-April \\
\hline 3 & Bheduria to Char Rustam & $100 \mathrm{~km}$ & Stretch of Tetulia river & March-April \\
\hline 4 & $\begin{array}{c}\text { Kalapara Golbunia point to the Confluence of } \\
\text { Bay of Bengal and Andharmanik river }\end{array}$ & $40 \mathrm{~km}$ & Andharmanik river & November-January \\
\hline 5 & Tarabunia to Vomkora & $20 \mathrm{~km}$ & Lower Padma river & Patuakhali \\
\hline
\end{tabular}

Table 2: Five established Sanctuary area of Tenualosa ilisha.

\begin{tabular}{|c|c|c|c|}
\hline SI. No. & Spawning ground & $\begin{array}{c}\text { Area of spawning ground } \\
\text { (square kilometer) }\end{array}$ \\
\hline 1 & Mayani point, Mirsarai & 125 \\
\hline 2 & Paschim Syed Awlia point, Tajumuddin & 80 & Chittagong \\
\hline 3 & North Kutubdia point, Kutubdia & 120 & Bhola \\
\hline 4 & Lata Chapali point, Kalapara & 194 & Cox's Bazar \\
\hline
\end{tabular}

Table 3: Four established spawning ground area of Tenualosa ilisha.

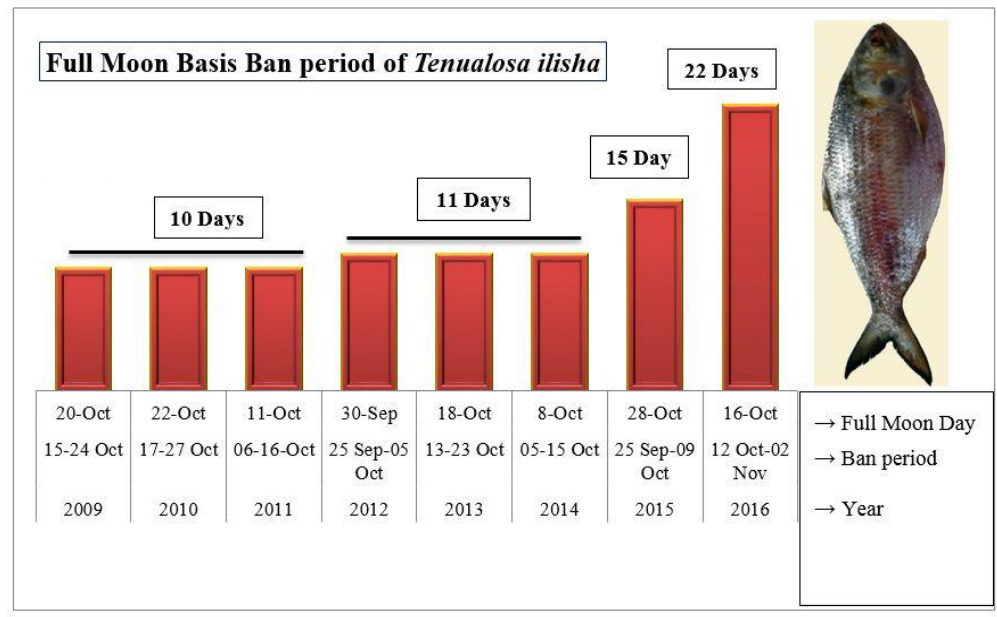

Figure 3: Full Moon basis ban period time frame from 2009-2016.

a. Research vessel (M.V. Rupali Ilish with speed boat) trip (Figure 4) and

b. Research trip with necessary research equipment's by using local transport system.

\section{Site selection}

Major spawning grounds of Hilsa and adjacent sites were selected and visited by the Hilsa Research Team for comprehensive study (Figure 5, Table 4).

\section{Data collection time frame}

Three sequential time frames were selected for sampling and data collection by the Hilsa Research Team such as:

i) Before ban period (10 days)

ii) Whole ban period (22 days)

iii) After ban period (10 days)

Determination of size, sex and percent composition of gravid/berried Hilsa

The length size and weight of Hilsa collected from the selected areas (Table 4) were calculated by the measuring scale and weight machine.
Through gentle stripping at their belly along the ventral scute line from anterior to anal direction with the fore and first finger together and by external observation, sex of Hilsa was determined. During the stripping, white milky or creamy liquid came out for the male and eggs with blood strain oozes out through the anus for the female. If such milky liquid or eggs did not come out, the fish was identified as either immature or premature stage. The potbellied Hilsa with reddish and bigger anus was also identified as female Hilsa.

\section{Spent and oozing Hilsa identification}

Identification of spent Hilsa was done by observing their external health condition such as lean, thin, shrunken belly and elongated body shape. Isolated and distorted eggs came out either with watery liquid or with blood strain. The spent Hilsa, locally called pite fish found to be very weak when captured from the rivers. The oozing Hilsa was identified by observing their egg releasing condition (Figure 6 and 7). It means the condition that without any pressure at their belly eggs came out from the vent automatically.

\section{Observations of Hilsa maturity stage}

Maturity stages of Hilsa captured from the selected sites were determined following Pillay [2]. 
Citation: Rahman MA, Pramanik MMH, Flura, Ahmed T, Hasan MM, et al. (2017) Impact Assessment of Twenty-Two Days Fishing Ban in the Major Spawning Grounds of Tenualosa ilisha (Hamilton, 1822) on its Spawning Success in Bangladesh. J Aquac Res Development 8: 489. doi: 10.4172/2155-9546.1000489

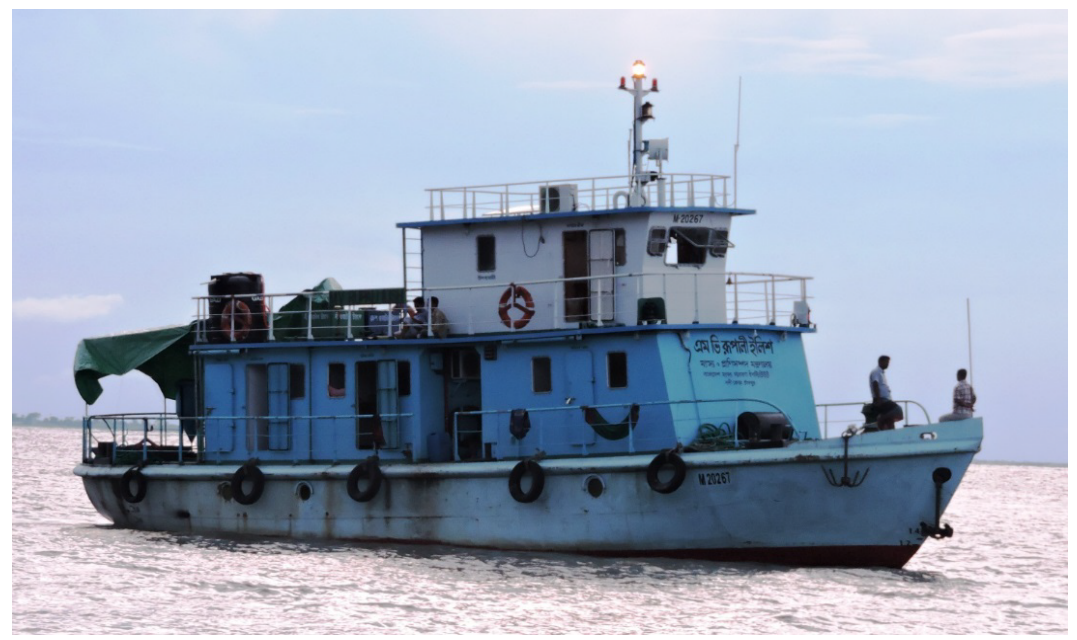

Figure 4: Hilsa research vessel 'MV Rupali Ilish'.

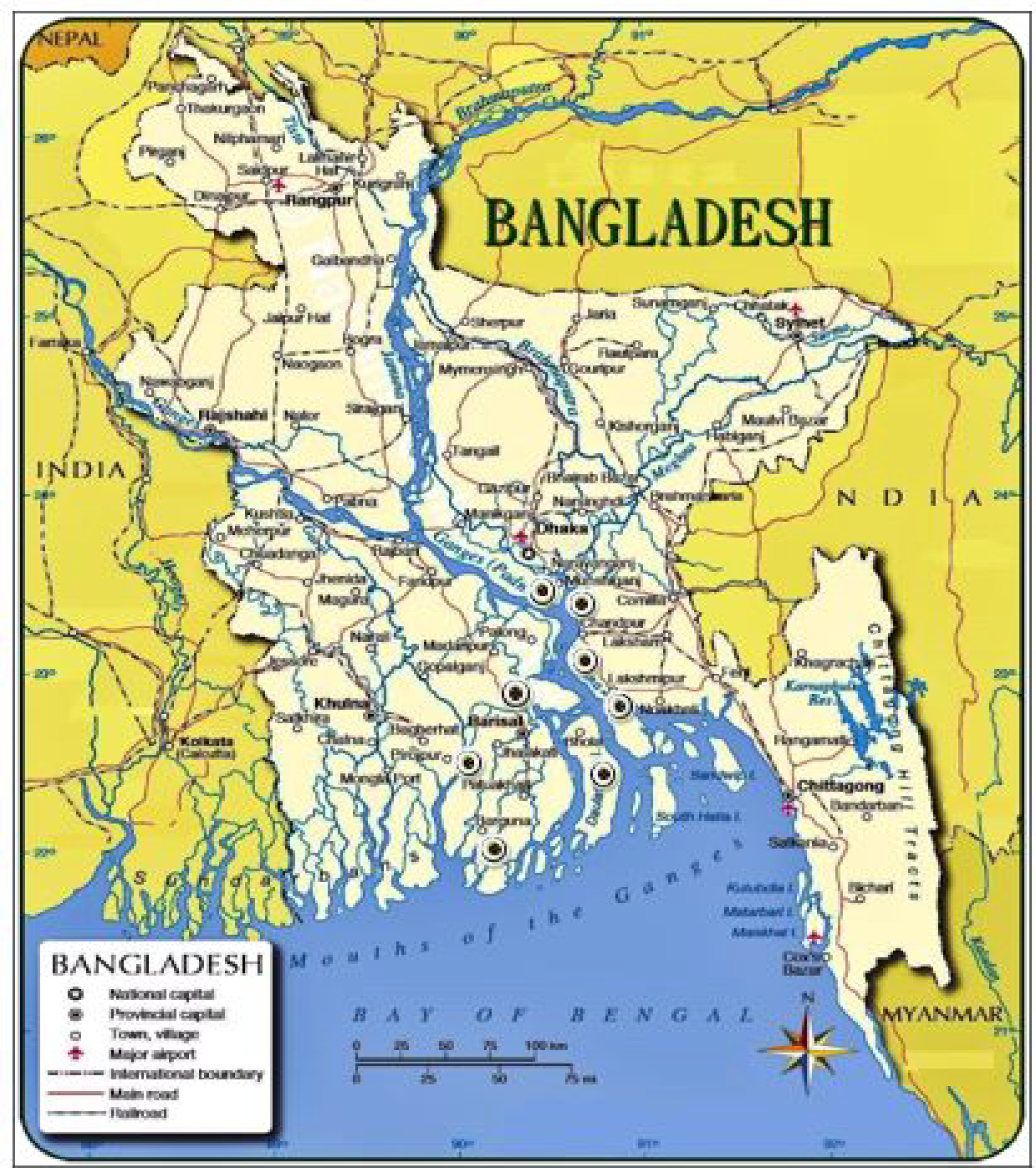

Figure 5: Map of Bangladesh showing selected districts (eight) for sampling and data collection. 
Citation: Rahman MA, Pramanik MMH, Flura, Ahmed T, Hasan MM, et al. (2017) Impact Assessment of Twenty-Two Days Fishing Ban in the Major Spawning Grounds of Tenualosa ilisha (Hamilton, 1822) on its Spawning Success in Bangladesh. J Aquac Res Development 8: 489. doi: 10.4172/2155-9546.1000489

Page 6 of 12

\begin{tabular}{|c|c|c|c|}
\hline SI. No. & Sites & District \\
\hline 1 & Chandpur, Katakhali, Horinaghat, Haimchar and Charvoirobi & Chandpur \\
\hline 2 & Tarabunia & Shariatpur \\
\hline 3 & Hizla, Mehendiganj, Ulania & Barishal & Meghna \\
\hline 4 & Ramgoti & Meghna & Noakhali \\
\hline 5 & Tanki Bazar, Chairman ghat, Hatia & Meghna estuary & Bhola \\
\hline 6 & Dhalchar, Moulovirchar, Daulatkhan, Monpura & Meghna estuary & Barguna \\
\hline 7 & Kalirchar, Patharghata & Meghna estuary & Patuakhali \\
\hline 8 & Mohipur, Galachipa, Kalapara & Andharmanik \\
\hline
\end{tabular}

Table 4: Selected sites for sampling.

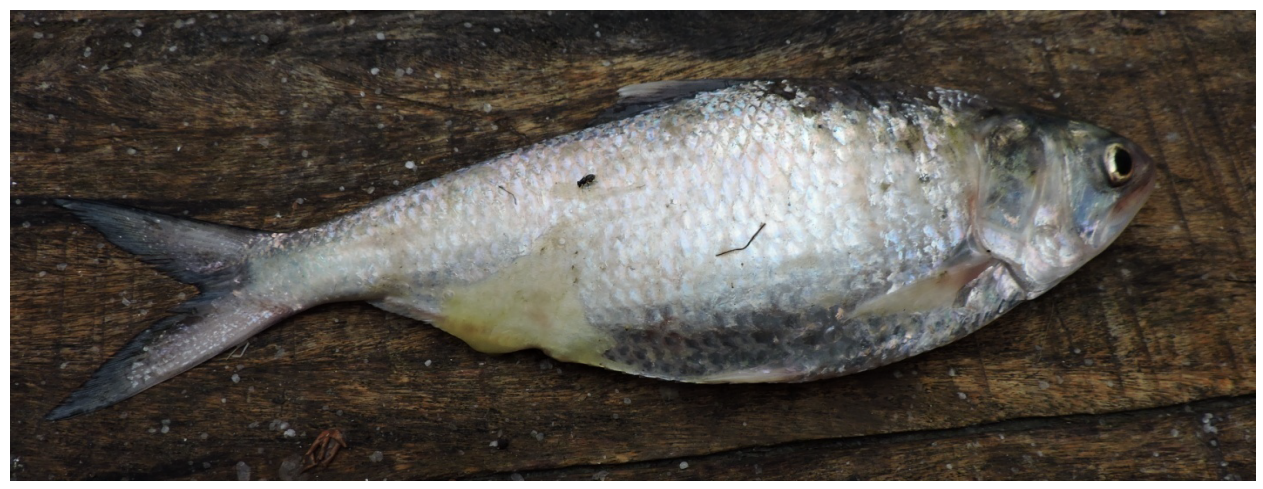

Figure 6: Pictorial view of oozing Hilsa (female).
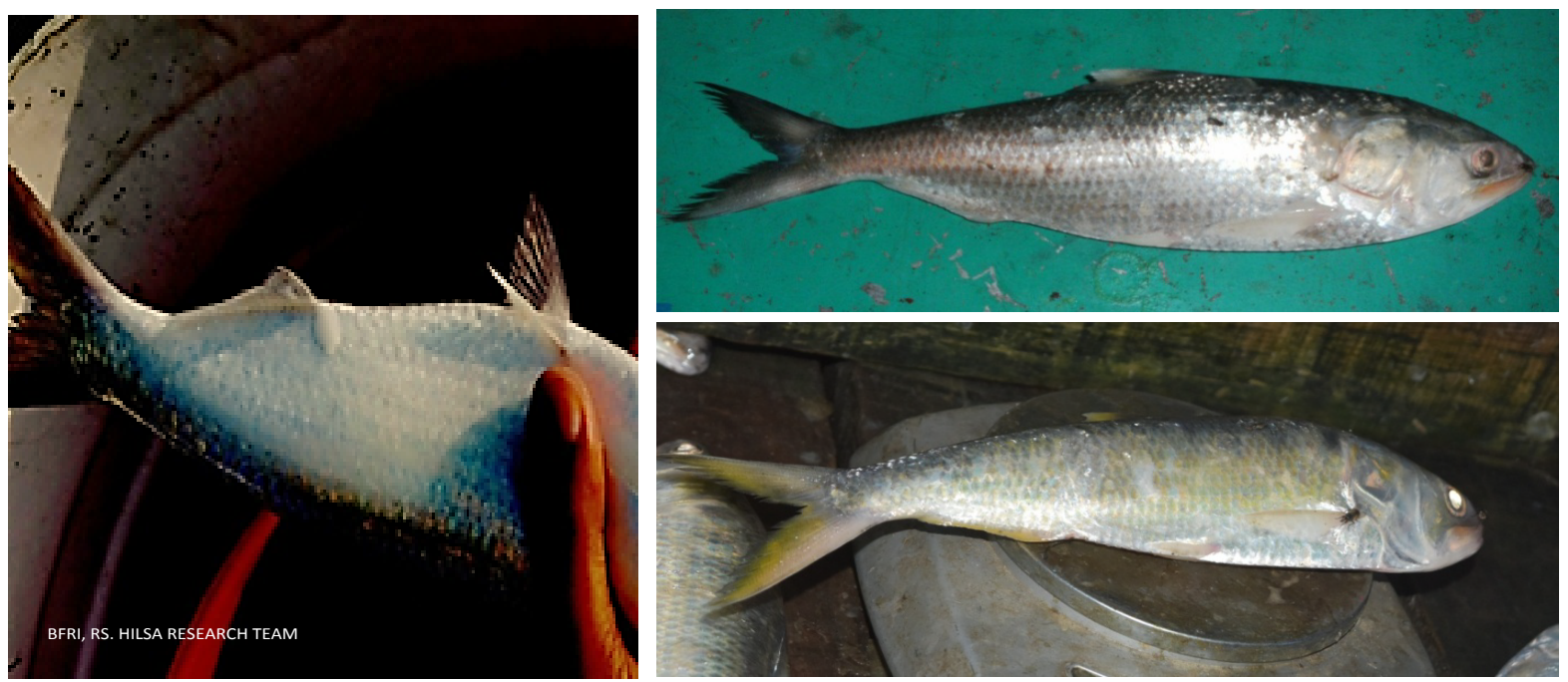

Figure 7: Pictorial view of oozing Hilsa (male) and spent Hilsa (male \& female).

\section{Percent composition of spent Hilsa}

The number and percent composition of spent Hilsa were determined by observing the catches of the commercial fisherman in and around the spawning grounds and nearest fish landing centers.

\section{Calculation of fertilized eggs during fishing ban}

The amount of fertilized eggs produced by Hilsa in the spawning grounds is an indicator of spawning success during the fishing ban and was estimated using the following formulae:
Total No. of Hilsa excluded due to fishing ban $(T N)=$ No. of fishing boat $\times$ Haul / day $\times$ Fish Caught $/$ Haul $\times$ No. of days

Total fertilized eggs $(\mathrm{Kg})=\frac{T N \times F F \times S F \times E F}{1000}$

Where,

$\mathrm{TN}=$ Total no. of Hilsa excluded due to fishing ban;

$\mathrm{FF}=\%$ of female fishes in the study sites;

$\mathrm{SF}=\%$ of spent Fish, and

$\mathrm{EF}=$ Average egg $(\mathrm{g})$ per fish. 
Citation: Rahman MA, Pramanik MMH, Flura, Ahmed T, Hasan MM, et al. (2017) Impact Assessment of Twenty-Two Days Fishing Ban in the Major Spawning Grounds of Tenualosa ilisha (Hamilton, 1822) on its Spawning Success in Bangladesh. J Aquac Res Development 8: 489. doi: 10.4172/2155-9546.1000489

Page 7 of 12

\section{Calculation of Jatka production}

The number of fry and Jatka production were estimated by calculating $50 \%$ hatching rate of the fertilized eggs and $10 \%$ survival rate of hatched larvae.

\section{Size, weight, age and CPUE calculation of Hilsa fry and Jatka}

Hilsa larvae were collected by BFRI Experimental Net from the spawning grounds and adjacent sites. Length and weight of Hilsa larvae and Jatka were measured by measuring scale and weight machine and then calculated. Approximate age of Hilsa fry and Jatka was measured by the field observations. CPUE (Catch per unit effort) was estimated by calculating the amount of Jatka $(\mathrm{kg})$ per $100 \mathrm{~m}$ net per hour.

\section{Observations of other impacts of fishing ban}

To check the supplementary benefit of 22 days fishing ban, BFRI Experimental Net was operated and fish samples were collected from the spawning grounds and adjacent sites. Collected samples were further analyzed for understanding the abundance and biodiversity of other freshwater fish species.

\section{Data analysis}

Microsoft Excel 2010 was used for data analysis.

\section{Results and Discussion}

\section{Size and sex composition of gravid Hilsa}

Gradually larger sized Hilsa were found in the catches of commercial fisherman as well as at the fish landing centers located from upstream of Chandpur to the downstream of Bhola during the field monitoring visits by the Hilsa Research Team. Most of the Hilsa were less than 35 $\mathrm{cm}$ in length in the upstream areas (39.89\% in Chandpur) whereas in the downstream areas most of the Hilsa were greater than $35 \mathrm{~cm}$ in length ( $85.4 \%$ in Bhola) represented by Table 5 . Similar findings were observed by Rahman, et al. [3]. Higher percentage of Hilsa with length group greater than $35 \mathrm{~cm}$ was observed in the downstream areas of Monpura and Hatia which is supported by Rahman, et al. [4]. Almost all the larger Hilsa found in the downstream areas were matured gravid Hilsa.

Male and female Hilsa were estimated to make up 34\% and 64\% respectively of the total catch, suggesting a male to female ratio in the major spawning grounds of about 1:1.94. The present findings are very similar to the study of Haldar [5] who found male-female sex ratio of about 1:2 in the major spawning grounds of Hilsa. Different observations were reported by Islam, et al. [6] who found male-female sex ratio of about 1:1.08 in the upstream region (Chandpur). Quereshi [7] recorded male-female sex ratio of about 1:1 during the monsoon but the female was found to be the dominant in October. Blaber, et al. [8] reported that male is more abundant among the smaller fishes. It is revealed from the present study that management interventions (22 days fishing ban) in the major spawning grounds have positive impacts on population regeneration.

\section{Determination of Hilsa maturity stage and percent composi- tion of oozing Hilsa}

Hilsa were found in larger numbers at advanced maturity stages (MS) in the spawning grounds than other adjacent areas. Most of the Hilsa were found at MS IV, MS V \&MS VI where MS V means before spawning and MS VI means oozing Hilsa from which eggs or milt runs out at catch with higher length group (Figure 8, Table 6). The percent of Hilsa was $81.76 \%$ at MS V with length group $46 \mathrm{~cm}-50 \mathrm{~cm}$ indicates that most of the larger Hilsa were gravid in the major spawning ground which is very similar to Rahman, et al. [9]. Due to the imposition of fishing ban the increased availability of matured gravid Hilsa were found in the spawning ground. No Hilsa was found to be identified as MS I at different length group (Table 6).

The percent composition of oozing Hilsa was found to be the maximum $(27.1 \%)$ at length group $31 \mathrm{~cm}-35 \mathrm{~cm}$ and lowest $(0.29 \%)$ at length group $46 \mathrm{~cm}-50 \mathrm{~cm}$ indicating that higher percent of Hilsa might take part in spawning at $31 \mathrm{~cm}-35 \mathrm{~cm}$ length group (Figures 6 and 7).

\section{Percent composition of spent Hilsa}

A large number of post spawn spent Hilsa was observed in the catches of commercial fisherman and nearby fish landing centers. 43.93\% spent Hilsa was recorded from the present study whereas Rahman, et al. [3] recorded $36.6 \%$ in the previous year (Figure 9). This data was compared to the data of GEF-BFRI studies by Haldar [5] and found $71.58,82.04,77.58,73.2$ and 87.86 times higher than that of 2002. This finding indicate that the imposition of 22 days ban on the catching of brood Hilsa ensured increased successful spawning of Hilsa in the major spawning grounds than the previous fishing bans.

\section{Production of fertilized eggs during the fishing ban period and spawning success}

In the present investigation $6,28,291 \mathrm{~kg}$ Hilsa eggs was found to be produced which is higher than the study of Rahman, et al. [3] who recorded 4,94,365 $\mathrm{kg}$ Hilsa eggs production in the year 2015 (Figure 10). These findings indicate that 22 days ban period in 2016 have more positive impacts on egg production than the 15 days ban period in 2015 .

\section{Production of Jatka during the fishing ban period}

The production of fry estimated as 3, 92,681 crores were found to be higher than the study of Rahman, et al. [3]. The production of Jatka estimated as 39,268 crores was also found to be increased than the previous study of Rahman, et al. [3] (Figure 10).

It means huge amount of Jatka entered into the present stocks which is a very good sign for Hilsa fishery in Bangladesh (Figure 11). It could be said that 22 days fishing ban might have strong reflection on the fry and Jatka production. Haldar [5] reported that complete fishing ban has a strong positive impact on Jatka abundance. Due to the increased trend of Hilsa eggs, fry and Jatka Hilsa production have been raised year after year (Figure 12A-12C).

\section{Size, weight, age and CPUE of Hilsa fry and Jatka}

In the present investigation, approximately 05 days -25 days old fries and Jatka were found in all the surveyed areas in and around the spawning grounds by BFRI Experimental Net collection which is almost same with the study of Rahman et al. (Figure 13, Table 7).

The estimated CPUE was $3.25 \mathrm{~kg} / 100 \mathrm{~m}$ net/hour in the present study which is much higher than the study of Rahman, et al. [3].

\section{Freshwater and marine water catch and increasing rate (\%) of Tenualosa ilisha}

Due to the conservation approach and fishing ban activities which started since 2001, Freshwater and Marine water catch have been increased day by day (Figures 12A-12C). As a result, the catch of Hilsa in Bangladesh has been found to be moderately stable till now. 
Citation: Rahman MA, Pramanik MMH, Flura, Ahmed T, Hasan MM, et al. (2017) Impact Assessment of Twenty-Two Days Fishing Ban in the Major Spawning Grounds of Tenualosa ilisha (Hamilton, 1822) on its Spawning Success in Bangladesh. J Aquac Res Development 8: 489. doi: 10.4172/2155-9546.1000489

Page 8 of 12

\begin{tabular}{|c|c|c|c|c|c|c|c|c|c|c|c|}
\hline \multirow{3}{*}{ SI. No. } & \multirow{3}{*}{ Sampling area } & \multicolumn{10}{|c|}{ Length group (cm) } \\
\hline & & \multicolumn{5}{|c|}{$<35 \mathrm{~cm}$} & \multicolumn{4}{|c|}{$>35 \mathrm{~cm}$} & \multirow{2}{*}{ Total $(\%)$} \\
\hline & & $15-20$ & $21-25$ & $26-30$ & $31-35$ & $\%$ & $36-40$ & $41-45$ & $46-50$ & $\%$ & \\
\hline 1 & Chandpur & 1.27 & 8.02 & 14.22 & 16.38 & 39.89 & 34.05 & 25.55 & 0.51 & 60.11 & 100 \\
\hline 2 & Horina, Chandpur & 2.36 & 11.5 & 18.69 & 31.36 & 63.91 & 22.37 & 13.2 & 0.52 & 36.09 & 100 \\
\hline 3 & Haimchar, Chandpur & 1.93 & 7.87 & 12.98 & 25.86 & 48.64 & 31.92 & 17.86 & 1.58 & 51.36 & 100 \\
\hline 4 & Charvoirobi, Chandpur & 0.59 & 17.27 & 15.27 & 20.1 & 53.23 & 26.18 & 18.18 & 2.41 & 46.77 & 100 \\
\hline 5 & Hizla, Barishal & 3.69 & 11.01 & 36.54 & 24.99 & 76.23 & 17.49 & 5.71 & 0.57 & 23.77 & 100 \\
\hline 6 & Ulania,, Barishal & 0.76 & 6.56 & 8.15 & 38.12 & 53.59 & 30.01 & 15.4 & 1 & 46.41 & 100 \\
\hline 7 & Char Ludhua & 0.55 & 16.44 & 27.41 & 22.27 & 66.67 & 27.8 & 4.53 & 1 & 33.33 & 100 \\
\hline 8 & Ramgoti, Laximpur & 0.46 & 4.72 & 13.14 & 18.42 & 36.74 & 51.76 & 9.5 & 2 & 63.26 & 100 \\
\hline 9 & Chairmanghat, Noakhali & 0.39 & 4.3 & 9.03 & 19.32 & 33.04 & 46.29 & 16.03 & 4.64 & 66.96 & 100 \\
\hline 10 & Hatia, Noakhali & 0.82 & 5.06 & 6.21 & 13.54 & 25.63 & 47.64 & 21.57 & 5.16 & 74.37 & 100 \\
\hline 11 & Ilisha, Bhola & 2.11 & 6.69 & 9.72 & 18.43 & 36.95 & 30.07 & 26.16 & 6.82 & 63.05 & 100 \\
\hline 12 & Moulovhirchar, Noakhali & 0.34 & 1.5 & 4.18 & 8.15 & 14.17 & 55.06 & 22.05 & 8.72 & 85.83 & 100 \\
\hline 13 & Monpura, Bhola & 0.75 & 1 & 2.7 & 10.15 & 14.6 & 60.23 & 17.61 & 7.56 & 85.4 & 100 \\
\hline
\end{tabular}

Table 5: Length size percentage of captured gravid Hilsa at different length group from the sampling areas.

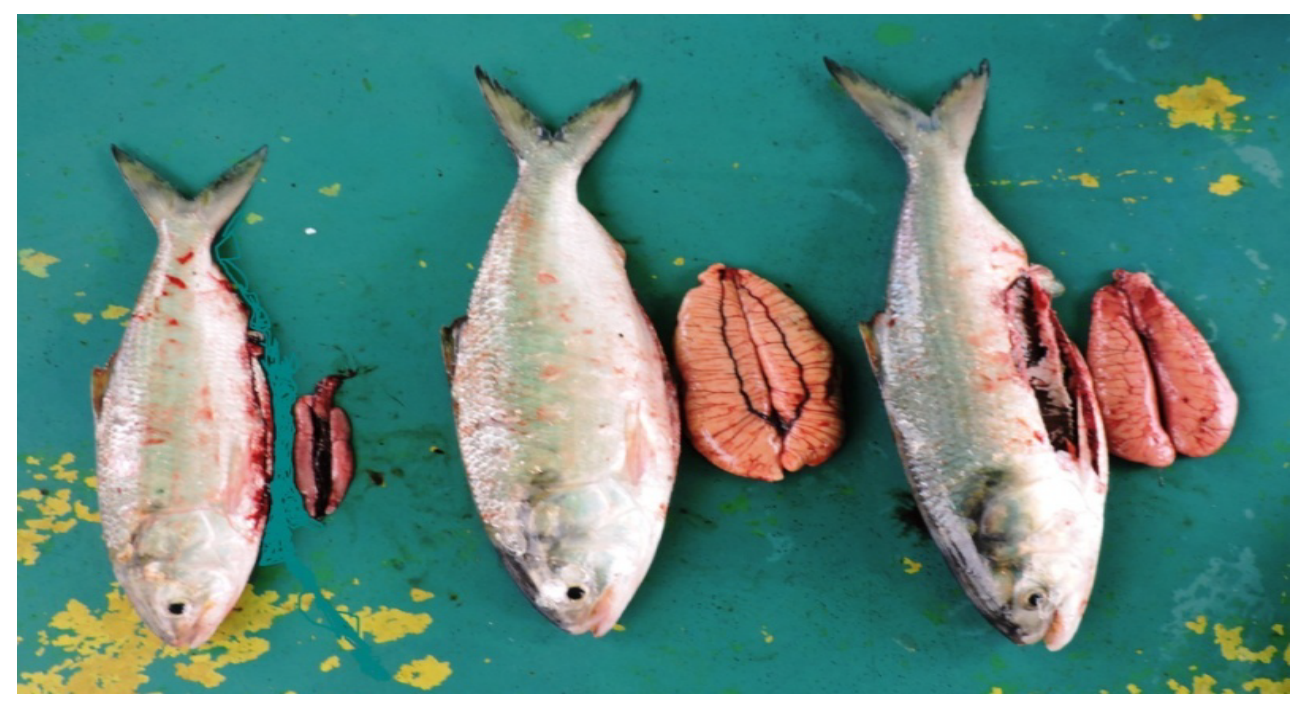

Figure 8: Maturity stages observation of Tenualosa ilisha.

\begin{tabular}{|c|c|c|c|c|c|c|c|c|}
\hline \multirow{2}{*}{ SI. No. } & \multirow{2}{*}{$\begin{array}{c}\text { Length } \\
\text { group }\end{array}$} & \multicolumn{7}{|c|}{ Percentage of Hilsa at different maturity stages (MS) } \\
\hline & & MS I & MS II & MS III & MS IV & MS V & MS VI & Total (\%) \\
\hline 1 & $20-25$ & 0 & 1.6 & 56 & 20 & 20 & 2.4 & 100 \\
\hline 2 & $26-30$ & 0 & 7.78 & 19.85 & 37.21 & 29.2 & 5.96 & 100 \\
\hline 3 & $31-35$ & 0 & 1.5 & 7.35 & 31.82 & 32.23 & 27.1 & 100 \\
\hline 4 & $36-40$ & 0 & 2.1 & 3.2 & 24.5 & 54 & 16.2 & 100 \\
\hline 5 & $41-45$ & 0 & 6.9 & 1.19 & 20.75 & 64.06 & 7.1 & 100 \\
\hline 6 & $46-50$ & 0 & 1 & 1.8 & 15.15 & 81.76 & 0.29 & 100 \\
\hline
\end{tabular}

Table 6: Maturity stages (MS) of Hilsa at different length group.

\section{Other impacts of 22 days fishing ban}

Due to the imposition of 22 days fishing ban, juveniles of other fresh water fish species were also found to be abundant along with Jatka in the spawning grounds of Hilsa and adjacent areas supported by Rahman, et al. [3]. Juveniles of 19 fresh water fish species were found in the present study such as Poa, Bele, Silong, Chela, Khorsula, Cuchia, Crab, Kolisa, Olufa, Baim, Kakila, Pangus, Taposi etc. The present findings indicate that 22 days fishing ban might have positive impacts on the abundance and maintenance of other fresh water fish species biodiversity. Location-wise fish species variations were found different (Table 8).

\section{Conclusion}

Hilsa being the national fish of Bangladesh have great socioeconomic and nutritional value [10]. The 22 days fishing ban has been found very effective and fruitful in the context of successful spawning of Hilsa and production of Jatka in the major spawning ground. 
Citation: Rahman MA, Pramanik MMH, Flura, Ahmed T, Hasan MM, et al. (2017) Impact Assessment of Twenty-Two Days Fishing Ban in the Major Spawning Grounds of Tenualosa ilisha (Hamilton, 1822) on its Spawning Success in Bangladesh. J Aquac Res Development 8: 489. doi: 10.4172/2155-9546.1000489

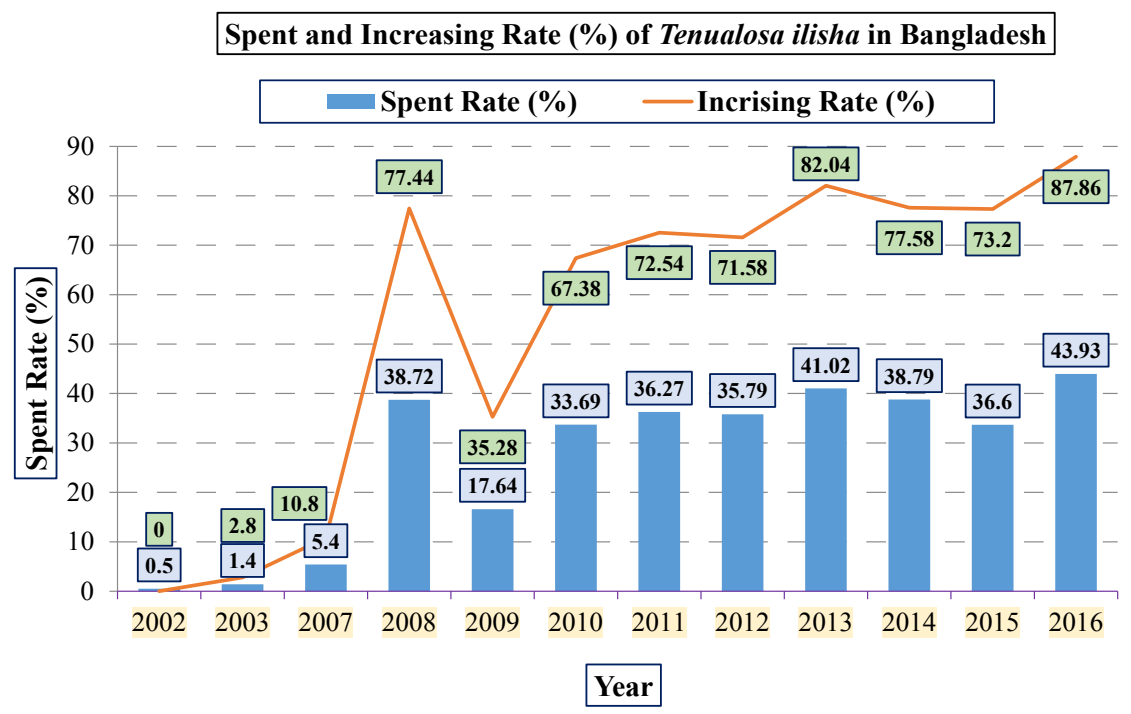

Figure 9: Spent and increasing rate (\%) of Tenualosa ilisha in Bangladesh.

\section{Eggs, fry and jatka Production of Tenualosa ilisha in Bangladesh}

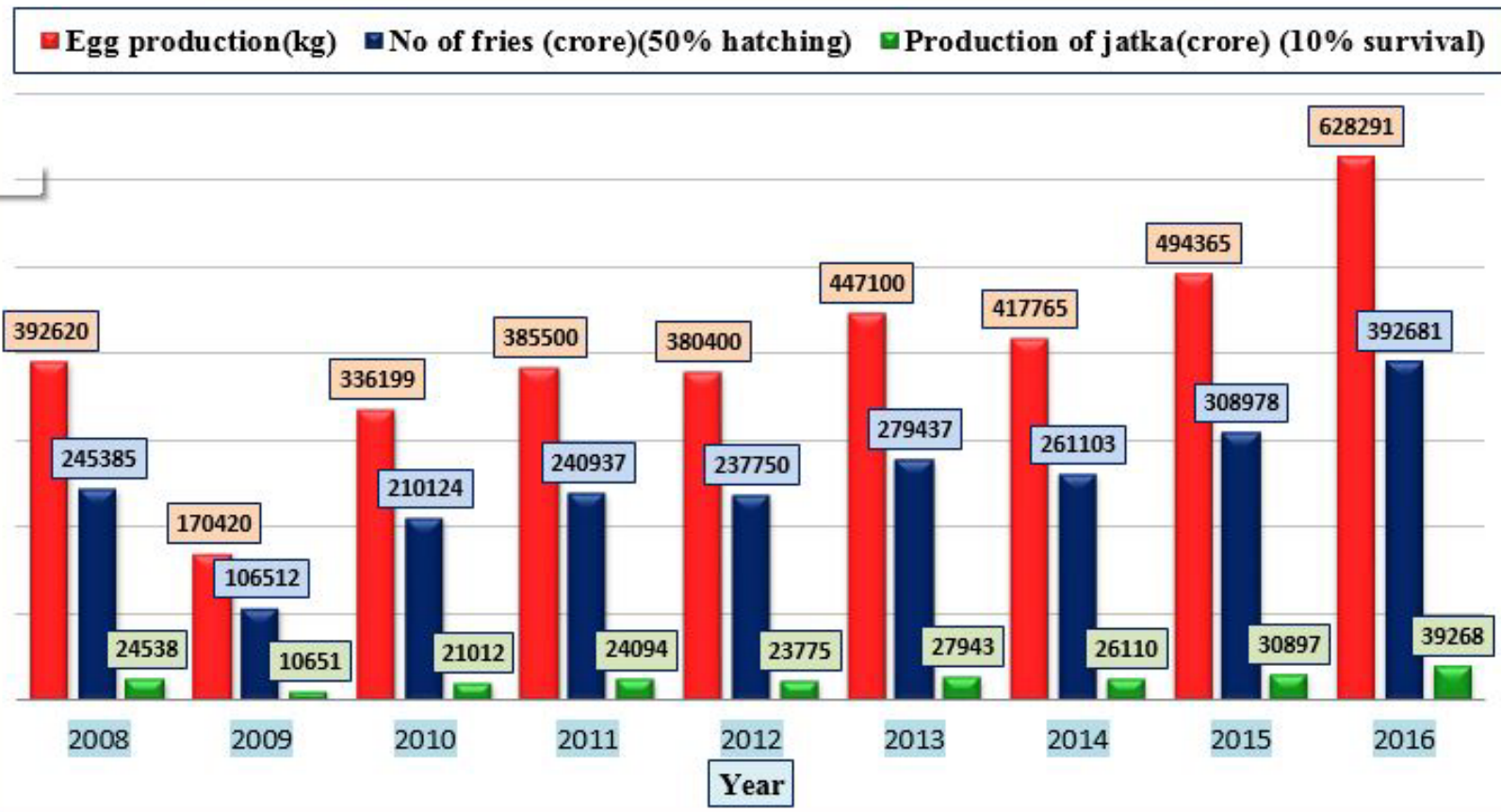

Figure 10: Eggs, fry and jatka production of Tenualosa ilisha in the major spawning grounds.

\section{Recommendations}

To conserve and to sustain the increased trend of Hilsa production following important management initiatives are recommended by the Hilsa Research Team, RS of BFRI:

1) Conservation of Jatka through fishing ban should be continued.

2) Fishing ban for the protection of matured gravid Hilsa for successful reproduction during the spawning season should be continued.
3) The impact of 22 days fishing ban on the breeding success of other fish species need to be assessed.

4) New nursery and breeding grounds of Hilsa need to be identified through further investigations.

5) Existing 4 major spawning grounds and 5 nursery grounds should be conserved and properly managed.

6) Time-worthy steps should be taken into consideration in the context of climate change. 

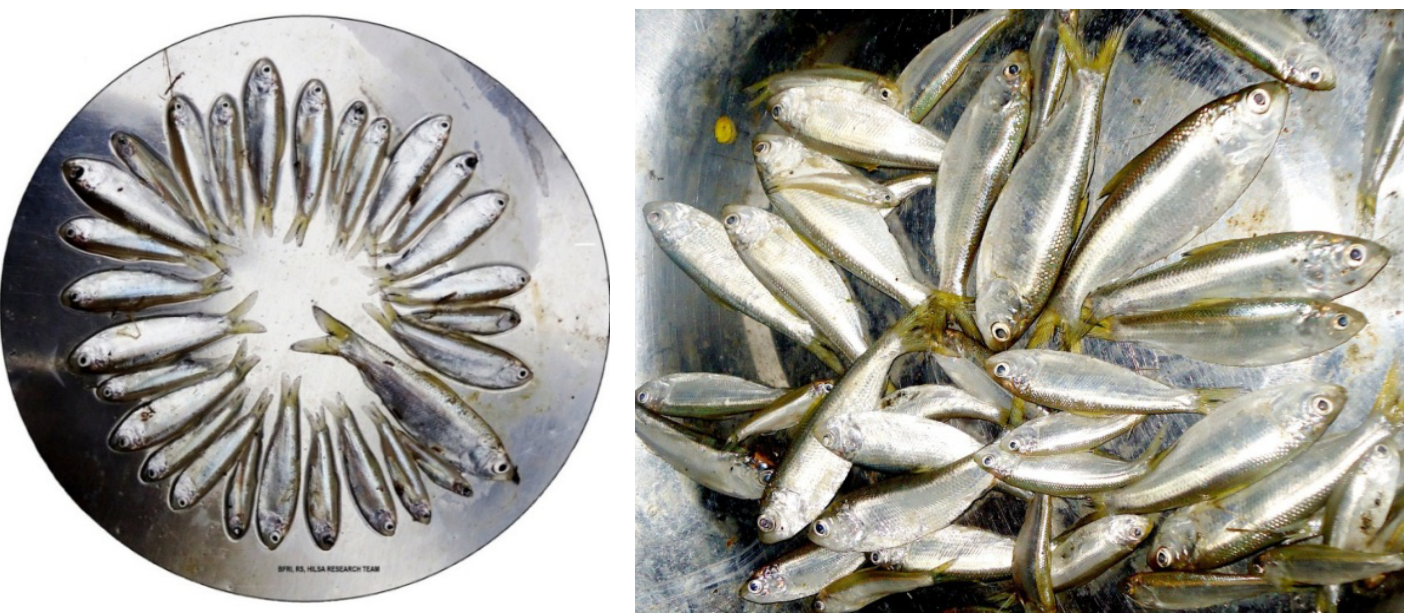

Figure 11: Observations of Tenualosa ilisha juveniles.

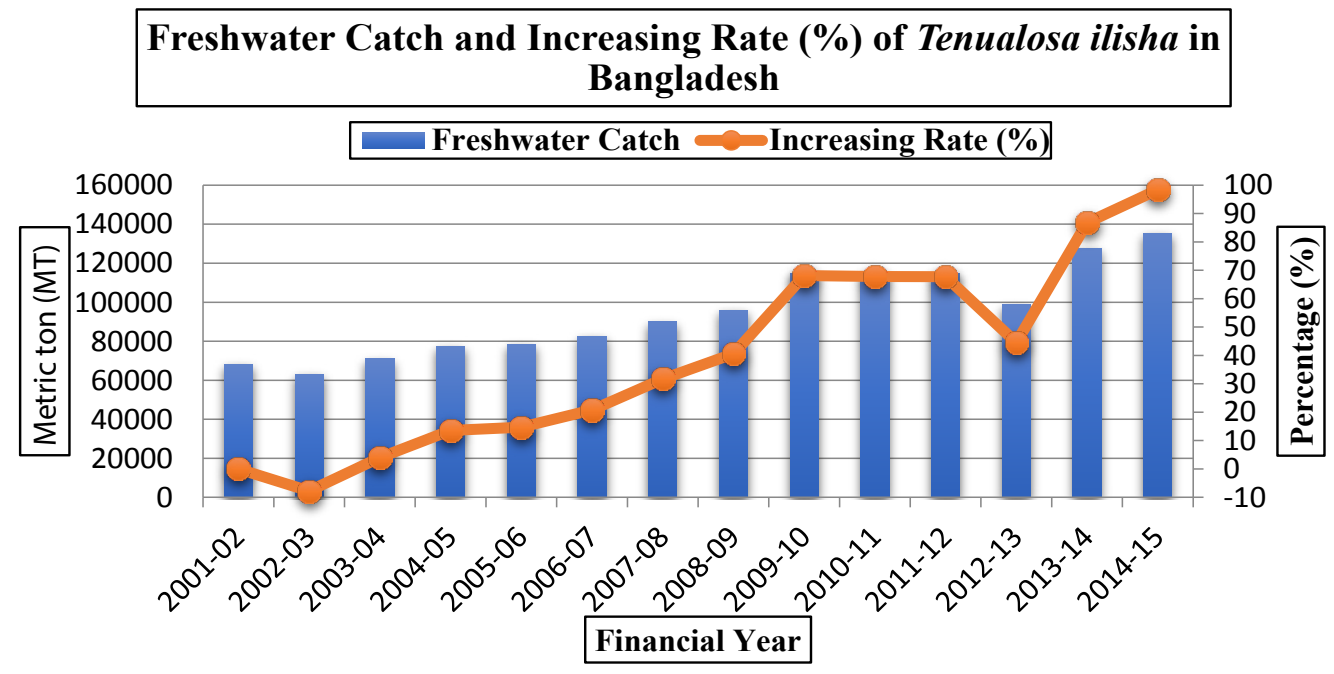

Figure 12A: Hilsa catch from freshwater (MT) in Bangladesh (2001-2015).

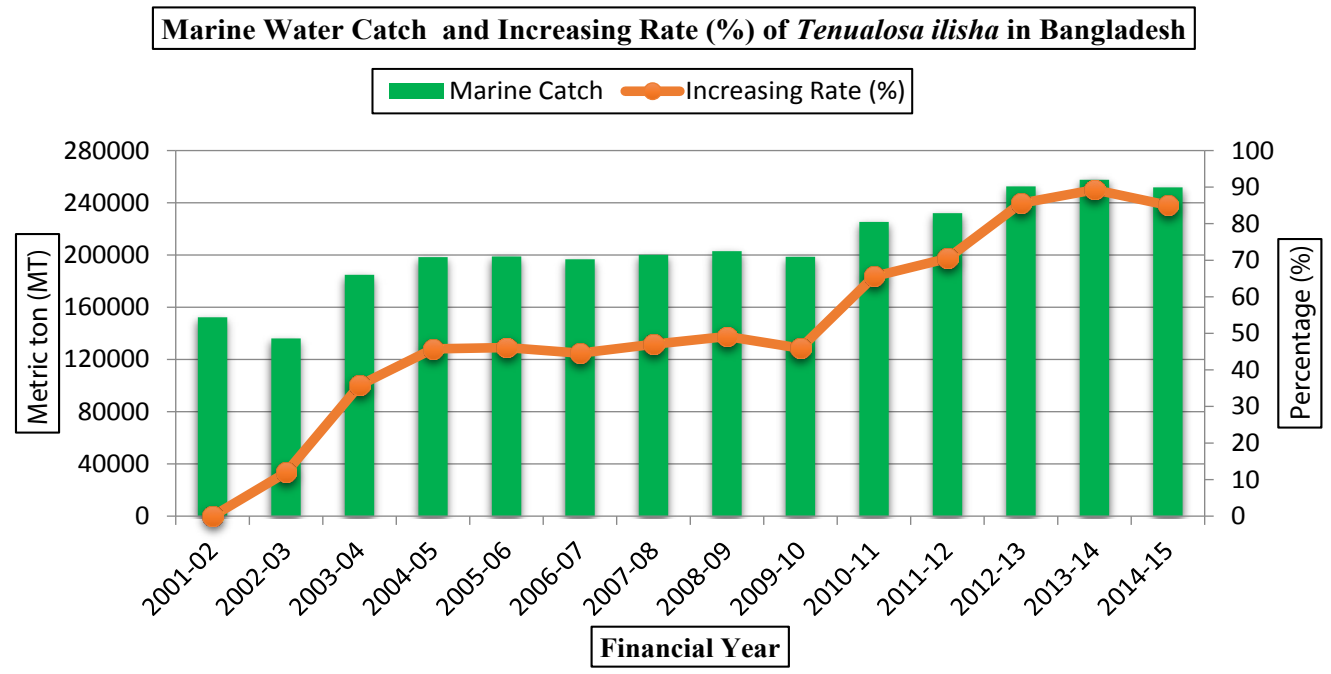

Figure 12B: Hilsa catch from marine water (MT) in Bangladesh (2001-2015). 


\section{Hilsa Catch [Fresh \& Marine Water] (MT) in Bangladesh}

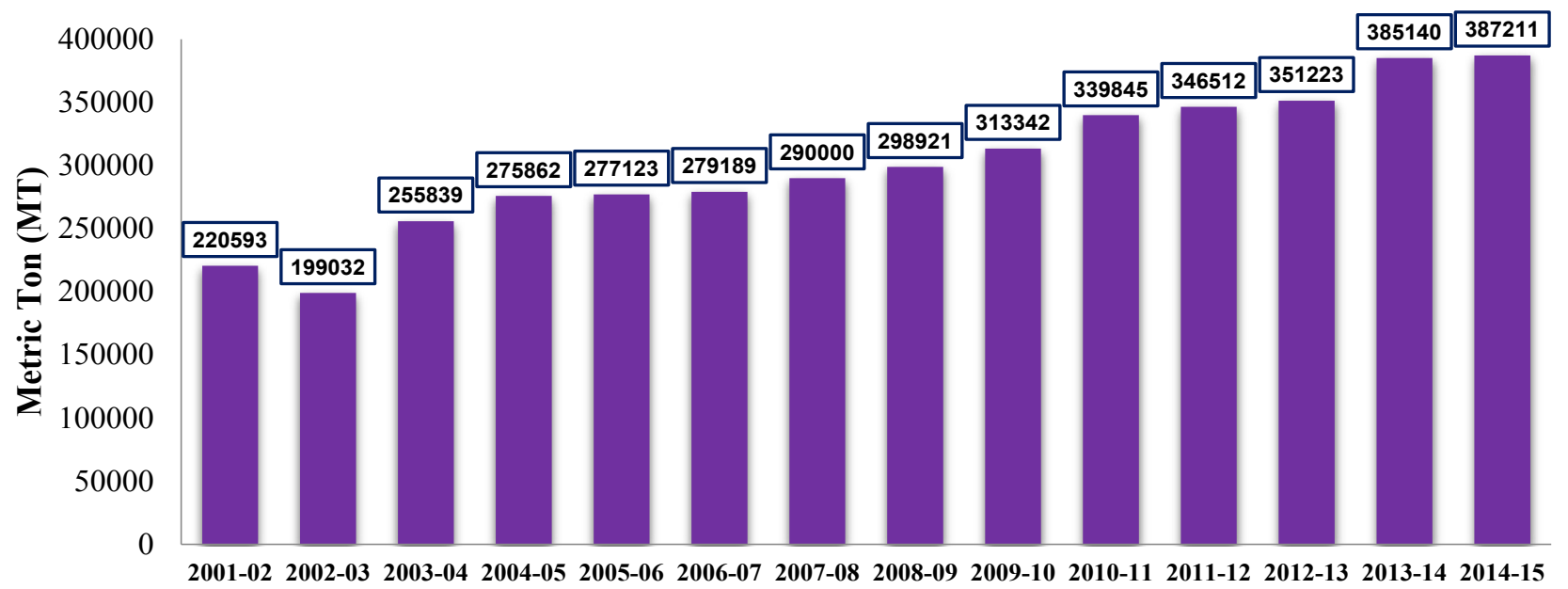

Financial Year

Figure 12C: Hilsa catch from both fresh and marine water (MT) in Bangladesh (2001-2015).

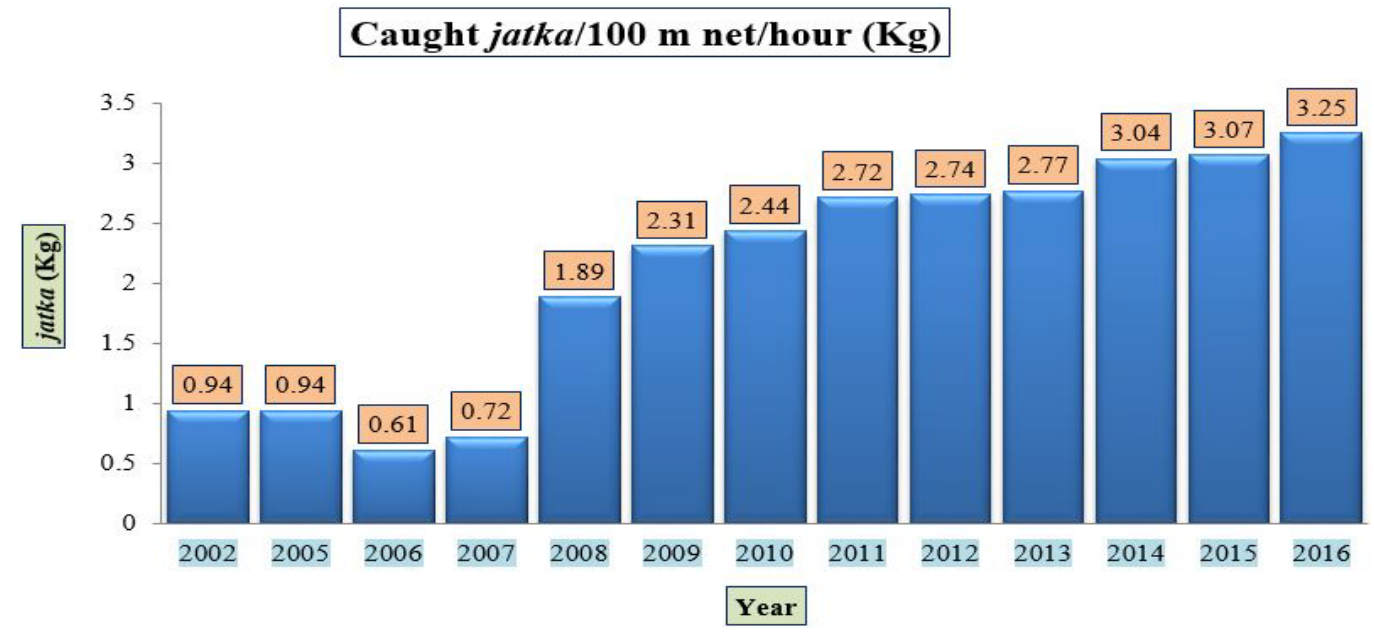

Figure 13: CPUE of jatka in the selected sampling sites.

\begin{tabular}{|c|c|c|c|c|c|c|c|c|c|}
\hline \multicolumn{2}{|c|}{ Location } & \multirow{2}{*}{\begin{tabular}{|c|c|}
$\begin{array}{c}\text { Lowest size } \\
\text { (cm) }\end{array}$ \\
1.57
\end{tabular}} & \multirow{2}{*}{$\begin{array}{c}\begin{array}{c}\text { Highest } \\
\text { size } \\
\text { (cm) }\end{array} \\
2.55\end{array}$} & \multirow{2}{*}{$\begin{array}{c}\begin{array}{c}\text { Average size } \\
\text { (cm) }\end{array} \\
1.85\end{array}$} & \multirow{2}{*}{$\begin{array}{c}\begin{array}{c}\text { Min. } \\
\text { weight } \\
\text { (g) }\end{array} \\
0.01\end{array}$} & \multirow{2}{*}{$\begin{array}{c}\begin{array}{c}\text { Max. weight } \\
\text { (g) }\end{array} \\
0.14\end{array}$} & \multirow{2}{*}{$\begin{array}{c}\begin{array}{c}\text { Average } \\
\text { weight } \\
\text { (g) }\end{array} \\
0.07\end{array}$} & \multirow{2}{*}{$\begin{array}{c}\begin{array}{c}\text { No. of } \\
\text { Jatka/Haul }\end{array} \\
22\end{array}$} & \multirow{2}{*}{$\begin{array}{c}\begin{array}{c}\text { Approx. age } \\
\text { (day) }\end{array} \\
10-15\end{array}$} \\
\hline \multirow{7}{*}{$\begin{array}{l}\text { Monpura, } \\
\text { Bhola }\end{array}$} & Ramnewaz & & & & & & & & \\
\hline & Sakuchia & 0.95 & 3.40 & 2.12 & 0.04 & 0.46 & 0.13 & 32 & $05-10$ \\
\hline & Janota bazar(HT) & 1.85 & 3.40 & 2.70 & 0.07 & 0.55 & 0.22 & 47 & $15-20$ \\
\hline & Janata bazar (LT) & 1.80 & 3.60 & 2.65 & 0.05 & 0.54 & 0.19 & 31 & $15-20$ \\
\hline & Hazirhat $(\mathrm{HT})$ & 1.67 & 3.80 & 2.62 & 0.04 & 0.57 & 0.15 & 58 & $15-20$ \\
\hline & Hazirhat (LT) & 1.65 & 3.60 & 2.60 & 0.04 & 0.45 & 0.16 & 55 & $15-20$ \\
\hline & Dhalchar & 2.20 & 2.90 & 2.60 & 0.13 & 0.30 & 0.15 & 46 & $20-25$ \\
\hline \multirow{2}{*}{ Bhola } & Moulovirchar & 1.91 & 3.10 & 2.40 & 0.10 & 0.56 & 0.20 & 37 & $15-20$ \\
\hline & Monpura & 1.20 & 2.65 & 1.86 & 0.07 & 0.59 & 0.18 & 32 & $10-20$ \\
\hline \multirow{2}{*}{ Chandpur } & Noyarhat & 1.70 & 3.60 & 3.0 & 0.20 & 0.66 & 0.28 & 60 & $15-20$ \\
\hline & Horina & 1.50 & 2.90 & 2.10 & 0.05 & 0.50 & 0.20 & 24 & $15-20$ \\
\hline \multirow{2}{*}{ Barishal } & Dhulkhola & 1.66 & 4.20 & 2.80 & 0.06 & 0.55 & 0.18 & 38 & $15-20$ \\
\hline & Hizla & 1.10 & 2.80 & 1.98 & 0.05 & 0.58 & 0.18 & 28 & $5-15$ \\
\hline Laxmipur & Ramgoti & 1.85 & 3.60 & 2.68 & 0.09 & 0.52 & 0.25 & 42 & $15-20$ \\
\hline
\end{tabular}


Citation: Rahman MA, Pramanik MMH, Flura, Ahmed T, Hasan MM, et al. (2017) Impact Assessment of Twenty-Two Days Fishing Ban in the Major Spawning Grounds of Tenualosa ilisha (Hamilton, 1822) on its Spawning Success in Bangladesh. J Aquac Res Development 8: 489. doi: 10.4172/2155-9546.1000489

Page 12 of 12

\begin{tabular}{|c|c|c|c|c|c|c|c|c|}
\hline \multirow{2}{*}{ Noakhali } & Hatia & 1.96 & 3.0 & 2.64 & 0.10 & 0.56 & 0.21 & 36 \\
\cline { 2 - 8 } & Chairmanghat & 1.83 & 2.95 & 2.32 & 0.08 & 0.60 & 0.22 \\
\hline \multicolumn{7}{|c|}{ HT: High Tide; LT: Low Tide } \\
\hline
\end{tabular}

Table 7: Size, weight and age of captured fries and Jatka from the major spawning grounds.

\begin{tabular}{|c|c|c|c|c|c|}
\hline SI. No. & $\begin{array}{l}\text { Bengali name/Local } \\
\text { name }\end{array}$ & Common group & Scientific name & $\begin{array}{c}\text { IUCN BD status } \\
2015^{*}\end{array}$ & $\begin{array}{c}\text { IUCN GB status } \\
2015^{*}\end{array}$ \\
\hline 1 & Poa & Flatheads & Otolithoides pama & LC & NE \\
\hline 2 & Bele & Mudskippers & Glossogobius giuris & LC & LC \\
\hline 3 & Silong & Catfishes & Silonia silondia & LC & LC \\
\hline 4 & Chela & Barbs and Minnows & Salmostoma acinace & LC & LC \\
\hline 5 & Khorsula & Mullets & Rhinomugil corsula & LC & LC \\
\hline 6 & Cuchia & Eels & Monopterus cuchia & VU & LC \\
\hline 7 & Kholisa & Labyrinth fishes & Trichogaster fasciata & LC & $\mathrm{NE}$ \\
\hline 8 & Red Chewa & Mudskippers & $\begin{array}{l}\text { Odontamblyopus } \\
\text { rubicundus }\end{array}$ & LC & NE \\
\hline 9 & Koral & Pony fishes & Lates calcarifer & NE & NE \\
\hline 10 & Vacha & Catfishes & Eutropiichthys vacha & LC & LC \\
\hline 11 & Kachki & Clupeids & Corica soborna & LC & LC \\
\hline 12 & Sada Chewa & Mudskippers & Trypauchen vagina & LC & NE \\
\hline 13 & Olua & Anchovies & Coilia dussumieri & LC & $\mathrm{NE}$ \\
\hline 14 & Kakila & Gars & Xenentodon cancila & LC & LC \\
\hline 15 & Baim & Eels & Mastacembelus armatus & EN & LC \\
\hline 16 & Pangus & Catfishes & Pangasius pangasius & EN & LC \\
\hline 17 & Topse/ Taposi & Threadfins & Polynemus paradiseus & LC & NE \\
\hline 16 & \multicolumn{5}{|c|}{ Crab } \\
\hline 17 & \multicolumn{5}{|c|}{ Chingri (small Prawn) } \\
\hline
\end{tabular}

Table 8: Identified fish species list with Bengali name, scientific name and conservation status.

7) River water pollution, navigation blockage, river breaching should be minimized.

8) Standardization of Hilsa fish landing and trading system.

9) Development of socio-economic condition and awareness building of fisherman.

\section{References}

1. DoF (2016) National fish week 2016 compendium (In Bengali). Department of Fisheries, Ministry of Fisheries and Livestock, Bangladesh.

2. Pillay SR (1963) Maturation and spawning of the Hilsa, Hilsha ilisha (Hamilton) of the Saurashtra Coast 30: 1

3. Rahman MA, Alam MA, Hasan SJ, Jaher M (2012) Hilsa fishery management in Bangladesh in Anon (ed.) Hilsa: Status of fishery and potential for aquaculture. The World Fish, Bangladesh and South Asia office, Dhaka.

4. Rahman MA, Flura, Ahmed T, Pramanik MMH, Alam MA (2015) Impact of fifteen days fishing ban in the major spawning grounds of hilsa (Tenualosa ilisha Hamilton1822) on its spawning success. Res Agric Livest Fish 2: 491 -

5. Haldar GC (2004) Present status of the Hilsa fisheries in Bangladesh: Report on Hilsa management and conservation studies conducted under the ARDMCS, GEF component, FFP.

6. Islam MS, Haq QM, Hossain M, Azad SA, NN Das (1987) Hilsa fishery in Bangladesh in 1985-1986. Hilsa Investigations in Bangladesh. FAO-UNDP Proj. Mar Fish Resour Manage, Bay of Colombo, Sri Lanka.
7. Quereshi MR (1968) Hilsa fishery in East Pakistan. Pakistan Journal of Science and Industry Research 11: 95-103.

8. Blaber SJM, Milton DA, Brewer DT, Salini JP (2001) The shads (genus Tenualosa) of tropical Asia: An overview of their biology, status and fisheries. Kuching, Sarawark.

9. Rahman MA, Rahman BMS, Hasan SJ, Flura, Ahmed T, et al. (2013) Impact of eleven days fishing ban in the major spawning grounds of Hilsa (Tenualosa ilisha) (Hamilton) on its breeding success. Bangladesh Research Publications Journal 9: 116-122.

10. Rahman MA, Ahmed T, Pramanik MMH, Flura, Hasan MM (2017) On-board breeding trial of Hilsa (Tenualosa ilisha, Ham. 1822) and testing of larval rearing in Bangladesh. J Aquac Res Development 8: 471. 